\title{
EL ESPACIO DEL CHOLO EN JOVEN, RICA Y PLEBEYA DEL DRAMATURGO BOLIVIANO RAÚL SALMÓN DE LA BARRA
}

\author{
THE SPACE OF THE CHOLO IN YOUNG, RICH AND PLEBEIAN OF THE \\ BOLIVIAN PLAYWRIGHT RAÚL SALMÓN DE LA BARRA
}

\author{
Jacqueline del Carmen Sandoval Avendaño \\ Universidad de Concepción, Chile \\ jacsandova@gmail.com
}

\begin{abstract}
Resumen: El dramaturgo boliviano Raúl Salmón de la Barra instaló en la escena teatral de los años cuarenta a dos figuras: el cholo y la chola, las que desde el siglo XVI aproximadamente, han sido considerados una contaminación del "mundo andino puro". Su obra Joven, rica y plebeya se inscribe en el marco de la producción literaria híbrida. Aquí el "uno" y el "otro", "conquistador y conquistado" son dos caras que se mezclan, lo que se visualiza especialmente en espacios dramáticos donde dialogan estrechamente objetos aymaras (aguayos en forma romboidal en las paredes) y objetos criollos (alfombras que combinan con el tapiz de las sillas, así lo hace ver la voz del dramaturgo). Esta mixtura da cuenta de una identidad chola que refiere a sus dos orígenes (aymara y occidental). De este modo, propongo un análisis aplicado a los espacios dramáticos que remiten a la memoria cultural de la madre chola y además a los espacios dramáticos que generan tensión en aquellos personajes que al parecer han aceptado los imperativos del criollo. Esta problemática está presente especialmente en Mary, la hija de la chola, quien al volver a su hogar no soporta vivir "entre cholos". Sin embargo, al finalizar la obra reconoce que una identidad se sustenta en la valoración de sus ancestros. En el análisis del espacio dramático trabajaré con Fernando Ainsa en Propuesta para una geopoética latinoamericana (2007); Ramón Griffero en Respuesta a un cuestionario de Rocío Fumey. Poética: la dramaturgia del espacio (2001); José García Barrientos y su texto Cómo se comenta una obra de teatro: ensayo de método (1992) y Cristopher Balme en Introducción a los estudios teatrales (2013).
\end{abstract}

Palabras clave: Cholo(a), identidad, hibridez, espacios teatrales, Raúl Salmón de la Barra.

Abstract: The Bolivian playwright Raúl Salmón de la Barra installed in the theater
scene in the 1940 s two figures: the cholo and chola, who since the sixteenth century
have been considered a contamination of the "pure Andean world". His work Joven,
rica y plebeya is part of the hybrid literary production. Here the "one" and the "oth- 
er", "conqueror and conquered" are two sides that are mixed, which can be seen in dramatic spaces where Aymara objects (Aguayos in a rhomboidal form on the walls) and Creole objects (carpets) interact closely. This mix of an identity has two origins (Aymara and Western). In this way, an analysis is applied to the dramatic spaces that refer to the cultural memory of the mother and others to the dramatic spaces that generate tension in some of the characters that have been considered as imperatives of the Creole. This problem is present especially in María, the daughter of the chola, who when returning when returning home does not stand living "among cholos". However, at the end of the work, Mary recognizes that an identity is based on the valuation of their ancestors. In the analysis of the dramatic space I will work: Fernando Ainsa in Proposal for a Latin American Geopoetics (2007); Ramón Griffero in Response to a questionnaire by Rocío Fumey. Poetics: the dramaturgy of space (2001); José García Barrientos and his text As commented on a play: essay of method (1992) and Christopher Balme in Introduction to theater studies (2013).

Keywords: Cholo(a), identity, hybridity, teaching, theater spaces, Raúl Salmón de la Barra.

Recibido: 30.03.2017. Aceptado: 19.03.2018.

\section{Introducción}

$\mathrm{R}$ aúl Salmón de la Barra, dramaturgo boliviano, escribe Joven, rica y plebeya (1989[1949]). La obra en análisis se inscribe en el marco de la producción literaria latinoamericana caracterizada por "su condición híbrida y ancilar” (Fernández Retamar, 1976: 90-91). Producción que, en palabras de Raúl Bueno (1991), "ha estado excluida del canon y ligada a una realidad histórica y a temáticas sociales de sectores excluidos del poder" (25). Esta obra en cuestión y especialmente el análisis de los espacios teatrales permite un debate sobre conflictos sociales presentes en aquella época. De este modo la producción dramática de Salmón es afín además a lo planteado por Carlos Rincón (1978), "las producciones literarias deben dar cuenta de los conflictos sociales, sobre todo en el campo del teatro" (17). De igual forma, es afín con lo que señala Augusto Boal (2002), "una obra de teatro debe generar cambios en una sociedad" (22). Y con lo que propone Stéphan (2011), "la mediación teatral debe generar en el espectador el deseo de transformar la sociedad en la que se vive" (15).

Ahora bien, el protagonismo está centrado en la hija chola; la que está en constante tensión con el criollo y consigo misma, ya que uno de sus orígenes, en especial el indígena, no es aceptado por aquellos que no aceptan 
tal diferencia. Este personaje principal habita tanto en espacios que dan cuenta de la alteridad chola como en espacios excluyentes de lo cholo. En este sentido esta obra perteneciente al teatro popular es convergente a lo señalado por Cornejo Polar (1994) escribir en el aire Ensayos sobre la heterogeneidad socio-cultural en las literaturas andinas, al referir a la literatura heterogénea como "aquella que surge y se reproduce a partir de una permanente situación de conflicto, producto de una condición colonial que tiene sus orígenes en la época de la conquista” (14). Posición que consiste "en negarle al colonizado su identidad como sujeto y separarlo de todos los vínculos que le confería aquella” (Cornejo Polar, 1994:19). Esta subordinación tiene sus orígenes en el periodo de la conquista, donde se agudizó la idea de establecer que aquel ser "hallado" debía estar supeditado a las costumbres y hábitos occidentales, lo que significó:

Problemas en los que se destrozaba al sujeto y pervertía todas las relaciones (consigo mismo, con sus semejantes, con los nuevos señores, con los dioses, con el destino y sus deseos) que lo configuran como tal. El sujeto surgido en una situación colonial no tiene una identidad coherente y uniforme, no es capaz de configurar un yo que siempre sea el mismo, se reconoce no en uno sino en varios rostros, inclusive en sus transformismos más agudos, muchas identidades disímiles y heteróclitas (Cornejo Polar, 1994:20-21).

La obra en análisis da cuenta de la hija de la chola, Mary, quien además de cambiarse el nombre (de Mariya a Mary), niega el espacio en el que habita porque le recuerda su origen, sobre todo el indígena. Esto se puede apreciar en la cantina y la salita aledaña a la cantina. Por otra parte, existen lugares en los que habita el criollo ${ }^{1}$ donde la exclusión es categórica y violenta. Estos son: el jardín del internado de señoritas y el elegante living room; en ellos no existen objetos propios de la mixtura aymara y occidental. Sin embargo, es aquí donde la hija de la chola y el criollo valorarán la identidad, lo que da cuenta del carácter transgresor. Esta puesta en escena de espacios híbridos y a la vez reivindicativos con la identidad chola es disidente a lo diseñado por el proyecto literario de mediados del siglo XX

\footnotetext{
${ }^{1}$ Aquel que ha aceptado los imperativos del poder hegemónico.
} 
en Bolivia; así lo hace ver Soruco Sologuren (2011) La ciudad de los cholos Mestizaje y Colonialidad en Bolivia en los siglos XIX y XX, "las páginas culturales de los periódicos y la crítica literaria menosprecia y emiten duros juicios sobre la producción de Salmón” (204). El dramaturgo es discrepante porque no centra su trabajo escritural solo en un referente: el occidente. Por ello, Soruco Sologuren (2011) señala que el calificativo más frecuente de sus obras es: "populachero" (Rivadeneira, 1999; Muñoz, 1992; Muñoz Cadima, 1981; Suárez Radillo, 1976) que se extiende a "chabacano, vulgar y bajo, grosero” (203). En síntesis, su producción literaria es calificada como aquel teatro popular que se contrapone al teatro culto, lo que da cuenta de una posición dicotómica. Esta postura tiene sus arraigos en las ideas instauradas por Alcides Arguedas en Pueblo enfermo (1979[1909]). Sus planteamientos entre otros son: "los cholos son una casta de gentes híbridas sometidas ya a un lento proceso de selección, pero que todavía no han alcanzado a eliminar de sí las taras de su estirpe" (39). Por otra parte, Franz Tamayo (1975[1910]) en Creación de la Pedagogía Nacional, de igual forma incide en los escritores de aquella época y propone una transformación del cholo basada en una educación regimentativa, ya que "el cholo es falto de racionalidad" (56). De esta forma, ambos pretenden una homogeneización y conversión del cholo. Lo que no sucede en las obras de Raúl Salmón, ya que la conversión sucede en el criollo y esta subversión ocurre en espacios que repulsan lo cholo. Respecto de la descalificación hacia el otro, Raúl Ruiz (1998) en su obra El Prometeo de los Andes, señala la diferencia social existente en Bolivia en las primeras décadas del siglo XX, además refiere a la exclusión de hijos de chola que asisten a colegios pagados:

En el año 1929, de tres y medio millones de habitantes, sólo tres familias tienen el poder económico en Bolivia (Patiño, Hochschild y Aramayo). Estos administran la economía nacional ligada al capitalismo internacional, con ingresos mayores que los del propio Estado. Luego en 1932 se inicia la guerra del Chaco, que lleva a los bolivianos y paraguayos a una guerra fratricida: poco o nada se dijo de los que fueron fusilados y masacrados, de los obreros, cholos e indios caídos en las luchas sociales. Desangra a un pueblo, ahonda la miseria y el hambre, lleva a la orfandad y el luto a miles de hogares y provoca, asimismo, el abandono de los campos. Los establecimientos escolares donde los niños permanecen hacinados, constituyen verdaderas incubadoras de enfermedades, un 
ejemplo de cifras: 2807 maestros y 49393 alumnos. Los hijos de la clase obrera económicamente restringida, acuden a escuelas privadas, si de algún modo un hijo de cholo se educa en este último la discriminación y la invisibilización será mayor (Ruiz, 1998: 23).

Ruiz presenta datos sobre la economía del pueblo boliviano de mediados del siglo XX aprox. Esto es relevante por cuanto Raúl Salmón pone en escena espacios que demuestran la discriminación de hijas de cholas en espacios que la burguesía criolla considera propios.

Ahora bien, los espacios teatrales presentes en Joven, rica y plebeya del dramaturgo serán analizados según lo planteado por Fernando Ainsa en Propuesta para una geopoética latinoamericana (2007), quien señala que los espacios teatrales son los que "rodean y envuelven... atmósfera, ambiente, contorno, zona, sitio, extensión distancia-nociones que componen un verdadero "sistema de lugares" del imaginario contemporáneo y un campo semántico de sugerentes significaciones” (10). García Barrientos (2012) en su obra Cómo se comenta una obra de teatro: ensayo de método, propone:

El espacio diegético es el conjunto de los lugares ficticios que intervienen o aparecen (es aquel) listo para ser representado en un teatro. El espacio escénico es el espacio real de la escenificación, el espacio teatral representante, con formas que varían según las diferentes épocas y culturas y plasmaciones concretas distintas en cada teatro (edificio) particular. El espacio dramático es la relación entre los espacios de manera específicamente teatral de representar los espacios ficticios del argumento en los espacios reales disponibles para su escenificación (151-152).

Cristopher Balme (2013) en Introducción a los estudios teatrales, señala:

El espacio mimético se refiere al espacio representado en escena y que es visible para el espectador, mientras que el espacio diegético sólo se describe o es aludido a través de los parlamentos de los personajes de la obra. El espacio mimético puede incluir también el espacio evocado por signos acústicos, como sonidos que provienen de fuera de escena, por ejemplo, aunque se relaciona principalmente con la escenografía y el diseño visual del espacio escénico (Balme, 2013: 104). 
Según Ramón Griffero en Respuestas a un cuestionario de Rocío Fumey en Poética: la dramaturgia del espacio (2011), plantea: "la palabra, el texto, genera una visualidad espacial como la visualidad espacial generará a su vez un texto. Decir te quiero será potencializado y cambiará su significado; si se está en la playa haciendo un castillo, al interior de un refrigerador, cortando el miembro a tu amante o siendo clavado a una plancha, etc., etc..." (76). De ahí que para dilucidar lo que significan requerimos de un contexto espacial.

\section{El espacio en Joven, rica y plebeya}

En la obra Joven, rica y plebeya los espacios son seis: el jardín de un internado religioso donde estudia la hija de la chola y donde además la exclusión de lo cholo es evidente; la calle, lugar que recibe el cuerpo del cholo agredido; la salita criolla, lugar del que es dueña la madre chola; la cantina, espacio donde el criollo demuestra lo que es; la habitación de la dueña, lugar donde el criollo irrumpe y donde es develada la verdad, y por último, la casa de los criollos, espacio de apariencias, donde lo cholo está prohibido. "Estos espacios conforman un campo semántico de atractivas consideraciones" (Ainsa, 2007). En cada uno de ellos veremos de qué forma transita el cholo, en algunos, su represión es severa, en otros, existe un despliegue de su identidad, la cual va acompañada de ambigüedades.

\section{Un jardín de un internado religioso}

Es un espacio diegético, lo que García Barrientos (1992) identifica como "aquellos lugares ficticios que intervienen o aparecen en un texto dramático” (151). El jardín del internado de igual forma alude a la idea de un bosquecillo, lo que en palabras del acotador es propio para el recreo de las alumnas. Por ello podemos agregar que existe alusión a un lugar ameno²,

${ }^{2}$ El mito de la edad de oro da lugar al tópico del Locus Amoenus, utilizado por la retórica y la poesía para la descripción de paisajes ideales. El tópico del paisaje ideal aparece por primera vez con Homero. El Jardín de Alcino constituye la representación de un lugar maravilloso. Cabe precisar, sin embargo, que el paisaje ameno aparece plenamente en el género bucólico en Los Idilios de Teócrito y en Las Bucólicas de Virgilio. Las Bucólicas re- 
tópico literario de origen occidental. Este bosquecillo se complementa con una pequeña gruta, lo que de igual forma está vinculado con la divinidad cristiana. Finalmente, algunos bancos rústicos de madera que, en congruencia con la gruta, pueden significar el puente para la contemplación y el estudio, la sencillez o la espera pasiva:

\section{ACTO PRIMERO}

El jardín de un internado religioso de señoritas. Ocupando todo el fondo: un muro de ladrillos que conecta con una calle (se supone la parte posterior del edificio). En el horizonte se ven los techos de las casas. Los rompimientos avanzando desde el primer término deben dar la idea exacta de un bosquecillo propio para el recreo de las alumnas. En un ángulo (izquierda) una pequeña gruta. Algunos bancos rústicos de madera y un barril colocado cerca de la gruta constituyen toda la utilería de la escena (1989: 7).

Así el discurso del acotador sitúa la acción en un jardín separado del espacio exterior-público por "un muro de ladrillos”. La separación interiorexterior impide de esta manera, el "contagio" producto de la inevitable relación entre lo criollo y lo cholo.

El jardín, que es parte del internado, está desconectado de la calle, espacio de lo público. Por esto, podemos decir que se caracteriza por la privacidad, pero además la negación de lo cholo, lo que se explicita en la voz del personaje que dirige el internado de señoritas: "SUPERIORA.-Insinúale que no te visite a menudo... las niñas..., Sabes ya como son ellas. Bastante hay con aquello de que guardamos reserva sobre los tuyos...” (21-22). Las

sulta capital porque fija las características del paisaje ideal y su oposición con la urbe. Virgilio confiere al paisaje ameno una serie de elementos codificados poéticamente, tales como el vergel, el crepúsculo, los árboles, la fuente, los animales paciendo, el motivo musical y erótico. Ciertamente, estos elementos funcionan exclusivamente a favor del placer. El paisaje virgiliano está regido por la temporalidad cíclica de la naturaleza, es el lugar de la eterna primavera y, en consecuencia, aparece como un territorio utópico. Los rasgos fundamentales del Locus Amoenus son la oposición entre campo y ciudad, el elemento musical, la ausencia de tiempo cronológico, el motivo erótico, el atardecer y del agua (citado por Alexis Candia en su artículo El paraíso perdido de Jorge Teillier. Rev. chil. lit., Santiago, n. 70, p. 57-77, abr. 2007. Disponible en <http://www.scielo.cl/scielo.php?script=sci_ arttext\&pid=So718-22952007000100003\&lng=es\&nrm=iso $>$. Accedido en 20 marzo 2017. http://dx.doi.org/10.4067/So718-22952007000100003. 
palabras, "los tuyos" refiere a su origen, por cierto cholo, y ante esta exclusión, la respuesta de la hija se explicita en la voz del acotador: "(Quiere decir algo y se contiene)" (22).

En esta escena reconocemos al personaje hija de chola, la que da cuenta de un estado de sumisión y pasividad. Luego, la prohibición de una de sus ascendencias se evidencia nuevamente en la voz de las compañeras: "CHARO.-Mary, no vuelvas a recibirla a esa tu sirvienta. Es feo para el colegio./LULA.-Y para nosotras, hija. Imagínate que Betty, mi prima, pensó que era tu madre y...claro yo desmentí sería un absurdo/ Mary.- Desde luego. Sería un absurdo" (29). Aquí, Mary no contradice a aquellas que no lograrían comprender que una hija chola pudiese estudiar en un espacio exclusivo para el criollo. Lo que Raúl Ruiz (1998) reconoce como un modo de categorizar y excluir a aquellos que no pertenecen a los grupos sociales hegemónicos que ejercen el poder (23).

El internado es un espacio que se traduce en elementos escenográficos que solo refieren a un espacio que da cuenta del origen occidental, habitado además por personajes criollos que controlan, ordenan y agreden lo cholo. Todas estas acciones son veladas bajo la imagen de un lugar idílico.

Según Griffero, "ver el hecho escénico que se construye a partir de la simbiosis de una poética del texto con aquella de espacio. Como texto y lugar, desde cómo se construyen, conforman el significado final” (76). Este significado alude a un espacio que se complementa con la voz de personajes criollos que no aceptan la alteridad y una hija de chola, Mary, que quiere decir algo y se contiene, de esta forma es invisible para el otro. Tzvetan Todorov (2003) señala: "conozco o ignoro la identidad del otro...; evidentemente no hay aquí ningún absoluto, sino una gradación infinita...” (195). Así, la hija de chola se sentirá:

"en falta, ante el mundo" y ante ellos mismos al descubrir que carecen de una identidad clara y distinta. Debido a ello buscan una identidad en la que se anulen las similitudes y los conflictos que entraña su heterogeneidad simbólica e imaginaria. Tratan de establecerse como sujetos homogéneos (Cornejo Polar, 1994:20-21).

Este espacio nos anticipa en la obra, así como el narrador omnisciente en una novela, que los personajes que allí habitan (especialmente la hija de chola) actuarán conforme a los paradigmas homogeneizadores. 


\section{La calle}

Es un espacio mimético, lo que según Cristopher Balme (2013) define como aquel espacio "representado en escena y que es visible para el espectador y...que puede incluir también el espacio evocado por signos acústicos, como sonidos que provienen de fuera de escena" (104). De este modo, adquiere visibilidad con la fuerte caída de Rigucho: "LULA.- ¿Está colgado, el señor?/ RIGUCHO.-Sí, señoritas.../LULA.- (Instando al grupo de chicas para que lo empujen) Entonces a la carga. iEmpujémoslo! (Lo hacen y sólo se oye el ruido que produciría la caída de un bulto humano sobre el empedrado)" (33).

La violencia ejercida de parte de los personajes femeninos hacia el otro genera nuevamente en la hija de la chola estados de pasividad y contención: "MARY.- (Grita desesperada pero ni siquiera sus compañeras llegan a oírle) iNo! iNo!” (34). La calle, espacio exterior-público, es además un espacio urbano de Bolivia que repulsa lo cholo, ya que no existe una voz de protesta ante lo sucedido.

Ramón Griffero señala: "en la poética del espacio interviene el cuerpo, el gesto, los sonidos, la música, la luz, los objetos, los elementos escenográficos, la construcción de lugares, el uso de planos y composiciones. El espacio se lee, genera ideas y emociones" (76). Las primeras escenas de esta obra aluden a un espacio que apela a las emociones del lector y espectador, ya que al existir un cuerpo violentado, tanto de Rigucho como de Mary, genera la compasión en el lector y espectador.

Así, el principio de Joven, rica y plebeya presenta dos espacios que se alternan, lo privado y lo público. Uno, el jardín del internado que es el espacio diegético y el otro, la calle que es el espacio mimético. Luego, lo cholo está censurado tanto en el espacio diegético (el internado) como en el espacio mimético (la calle). El internado es el espacio de la hostilidad hacia lo cholo, de la contención de los cuerpos, de las manifestaciones de tristeza. La calle recibe el cuerpo agredido y expulsado de Rigucho, el cual es castigado al intentar entrar a un espacio exclusivo del criollo.

\section{La salita criolla}

Este espacio es diegético, lo que García Barrientos (2012), define como “el 
lugar ficticio que aparece listo para ser representado” (151).

\section{ACTO SEGUNDO}

Desde esta salita criolla - por la puerta foro- se advierte un espacioso jardín o patio con algunos árboles y sendas propias de una Quinta de Recreo en la que están algunas mesas cubiertas de manteles y los clásicos sapos. A juicio del director de escena, puede o no haber desplazamiento de comparsas (mozos, parroquianos, etc.) La salita tendrá una puerta lateral y la que da al foro, ya citado. La alfombra deberá guardar relación con el color del tapiz de los muebles de la sala, muebles éstos imprescindibles en las salitas criollas. Las paredes están adornadas con pequeños aguayos indígenas colocados en sentido romboidal, sobre los que destacan fotografías o tarjetones. Mesitas esquineras, radio-receptor, una vitrola y otros muebles de permanente moda llenan la habitación (Ninguno de los muebles nombrados tiene uso en el juego escénico pero sirven para ambientar y distinguir el contraste que se verá en el acto tercero) (35-36).

El discurso del acotador refiere a la alfombra, la que debe guardar relación con el color del tapiz de los muebles, lo que a su vez se mezcla con las paredes adornadas con "pequeños aguayos indígenas en forma romboidal" (36). Esta descripción une dos caras, lo indígena y lo criollo, en un "entramado que no admite divisiones: en cada sujeto existe el "uno" y el "otro", el dominante y el dominado...” (Valdés, 1989: 6). Néstor García Canclini en Culturas híbridas. Estrategias para entrar y salir de la modernidad plantea que una identidad no puede definirse de modo categórico, ya que es parte de un proceso en contante cambio,

procesos de hibridación que han estado presentes desde que comenzaron los intercambios entre sociedades; sin embargo, en la década final del siglo XX (época moderna), se extiende el análisis de hibridaciones a procesos culturales, especialmente la literatura. En ella, veremos la fusión muchas veces presente en los sectores populares de ascendencia indígena que emigraron del campo a la ciudad. Estos se vieron en la necesidad de pactar con la sociedad urbana (2010: 17).

Esta mixtura está presente en la dramaturgia de Salmón, especialmente en la identidad que habita en la ciudad de la Paz en espacios teatrales 
donde se demuestra la negociación de sus saberes. Por ende, podemos decir que esta salita criolla alude a la alteridad latinoamericana figurada en la chola y el cholo, aquel que

está instalado en una red de encrucijadas múltiples y acumulativamente divergentes tiene una índole abigarrada, excepcionalmente y es cambiante y fluido, lo cual es concomitante con la realidad en la que participa hecha de fisuras y superposiciones que acumula varios tiempos en un tiempo, y que no se deja decir más que asumiendo el riesgo de la fragmentación del discurso que la representa y la constituye, se trata de un sujeto que no tiene una identidad coherente y uniforme, complaciente y desproblematizada, no es fuerte, ni sólido, ni estable, no es capaz de configurar un yo que siempre sea el mismo. Se reconoce no en uno, sino en varios rostros, inclusive en sus transformismos más agudos... muchas identidades disímiles y heteróclitas singulares (Cornejo Polar, 1994: 20).

En estos espacios existen elementos escenográficos de ascendencia indígena (los aguayos) y elementos escenográficos que son propios de una sociedad criolla de los años cincuenta en la ciudad de la Paz (muebles éstos imprescindibles en las salitas criollas). La salita criolla nombrada en diminutivo es descrita en forma detallada por el discurso del acotador; entre ellos: "la alfombra, la que debe guardar relación con el tapiz de los muebles; y los aguayos los cuales están ubicados en forma romboidal” (35). Estos objetos no están dispuestos solo para completar el espacio, sino como lo advierte el acotador necesarios para generar un contraste entre el espacio del cholo y el living de la criolla, lo que se verá en el tercer acto. Existen, además, artefactos electrónicos que dan cuenta de un tiempo mezclado: radio receptor (mediados del siglo XX) y vitrola (inicio del siglo XX), lo que de igual modo da cuenta de la alteridad figurada en la madre chola.

En esta sala criolla es donde se produce el primer despliegue de la hija de chola: "MARY.- ¿han creído que me pueden tener metida toda la vida entre estas gentes? Mi padre no dijo que estudiara para venir a meterme en una cantina y entre... (Se contiene cuando quiere decir la palabra: cholos) ¡Oh! iMañana mismo quisiera volver al colegio! (Sale llorando)” (39). Este espacio, que alterna lo indígena y lo occidental, es el lugar en el que la hija de chola deja de estar contenida. Sin embargo, no quiere estar, ya que al parecer se acostumbró a vivir en el internado, donde paradójicamente es 
reprimida. En conclusión, esta salita caracterizada por su hibridez permite el primer despliegue de la hija de la chola. A su vez nos permite reconocer sus estados contradictorios, ya que anhela volver a un espacio excluyente donde le exigen contención y negación de su identidad.

\section{La cantina}

Este espacio es diegético, está ubicada en forma aledaña a la salita criolla donde habitan la madre chola y la hija. Es visible por primera vez cuando es nombrado por la hija de la chola: "mi padre no dijo que estudiara para venir a meterme en una cantina" (39). El texto refiere a la incompatibilidad entre el espacio el internado caracterizado por la armonía y la homogeneización, y la cantina o la salita criolla caracterizados por la heterogeneidad; estos últimos no se condicen con el anhelo de Mary que quiere pertenecer a la sociedad de casta. Sobre este afán de aparentar, Montecino (2010) señala:

ha quedado como huella de nuestro ser mestizo, favorecer por ejemplo, valores como el "el culto a las apariencias". Este rasgo pervive y se actualiza en nuestro territorio, tal vez como otros ademanes que los históricos, pero con visajes que evocan el "ladinismo" de hacer aparecer la realidad como algo que no es. Por ello, el simulacro será una de las actitudes evidentes de la constitución mestiza, la puesta en escena de su singularidad (52).

Luego, la cantina es visualizada nuevamente a través del criollo, personaje que aparece por primera vez en el acto segundo. Aquí se envalentona ante sus amigos y se autopropone engañar a la dueña, la que él supone debe ser una chola. Esta actitud de violencia es propia de su relación con lo cholo. Al respecto, Mabel Moraña, en el prólogo del texto Escribir en el aire. Ensayos sobre la heterogeneidad socio-cultural en las literaturas andinas (2003), plantea:

La cultura latinoamericana parte de la violencia fundacional de la colonización y se perpetúa en la violencia relegitimada del republicano, en que se afirma, de la emancipación a nuestros días, el sistema de privilegios de las elites criollas. Esa violencia se prolonga, luego en la perversidad subrepticia de la modernidad: en sus jerarquías y marginaciones sociales. Su autoritarismo político y su despojamiento (10). 
De esta forma, la cantina es el espacio público donde el criollo hace notar su supremacía:

WILLY.- (Del foro, por la izquierda, como si terminara de hablar con los muchachos y el mozo) iA ver! ¿Aquí es la habitación de la dueña? (El garzón asiente con la cabeza) iA mí me aceptará el vale! iDéjenme a mí! iDéjenme solo! (Los otros se retiran) iBuenas! (Llama con palmadas) ¿Dónde estará esa chola? iHola! (Avanza hasta el centro de la sala) iSeñora! (49).

Así, este espacio, negado por aquellos que están sumidos en estados de apariencias, permite reconocer la posición de privilegio que se adjudica el criollo ante la chola; a la vez es el puente para que el problema estalle, ya que es el punto de acceso a otro espacio donde el criollo descubre a Mary.

\section{La habitación de la dueña}

Este espacio es diegético; aquí, el criollo evidencia su altanería, lo que se visualiza en su gesto y su pregunta. Estas acciones del criollo generan en el lector el cuestionamiento de por qué siendo un espacio privado, se permite entrar. Aquí reconocemos además la relación amorosa que existe entre el criollo y la hija de la chola, de igual modo reconocemos la desigualdad social de aquella época:

WILLY.-Has sabido fingir... iTrataste de hundirme en el ridículo! / MARY.- ¿Por qué? ¿Porque en mi historia hay una pollera? ¿Por qué el amor jamás podrá unir a un marqués con una cocinera? ¿O por qué el prejuicio social hace de los hombres unos cobardes? (Suplicante) iNo, no! Willy, no me hagas caso. Estoy para perder la cabeza por lo que acaba de suceder. ¿Sabes que en estas dos semanas sin verte me ahogaba en esta casa? iNecesito libertad, la libertad que tú me darás! (50).

Aquí, el criollo da a conocer, al igual que Mary, su anhelo de simular ante los otros (Montecino, 2010). Por otra parte, el personaje femenino presenta nuevamente un despliegue, esta vez para defender su identidad; lo que se evidencia al argumentar su posición de repudio ante la descalificación del origen cholo. Sin embargo, vuelve a presentarse vulnerable ante el temor de que el criollo la rechace. Por ello huye con él, sin antes robar 
a su madre a pedido del criollo: "WILLY.-No tengo dinero...hoy/MARY.Llevaré conmigo/WILLY.-Necesitaremos bastante./MARY.-De eso no te preocupes" (51).

\section{El living room}

Este espacio es diegético, es decir, está constituido por un "conjunto de lugares ficticios que intervienen o aparecen listos para ser representados en un teatro" (García Barrientos, 2012:152).

\section{ACTO TERCERO}

Un elegante living.room. El hall pude verse desde el foro. El ambiente lleno de elegancia por su refinamiento y buen gusto, contrastará con el ambiente criollo del acto segundo (57).

Este espacio lleno de elegancia, como así lo señala la acotación, contrasta con la salita criolla, ya que este último refiere a los aguayos indígenas. Entonces, la elegancia entendida por las sociedades de castas es contraria a la hibridez presente en los espacios de lo cholo.

En el living room conocemos a la madre criolla y su marido y a la vez la relación que existe entre ellos: "ELISA.- ¿Supongo que no me culparás de no haber podido salvar la hipoteca de esta casa? Porque yo.../GUILLERMO.Te acuso, te culpo y te responsabilizo./ELISA.- ¿A mí? (histérica) ¿A mí? ¡OH! iLo único que faltaba! iUna blasfemia!” (58).

Este espacio es habitado por personajes que están a punto de perder su casa. Aquí se hace presente la madre chola que ha estado en búsqueda de su hija (la que se fugó con el criollo). La madre criolla percibe la desesperación de la chola y tratará de aprovecharse. Exigiendo una indemnización por el engaño:

ELISA.- (Aprovechando el tono humilde y el dolor de Faustina) Llora usted como si fuera una damnificada. No. Yo pediré reparaciones ante la justicia porque su hija lo engaño a mi Willy. Con ese dinero lo engatusó. ¿Qué mujer honrada hace esto! iEste es un engaño a la inocencia juvenil! /FAUSTINA.- iHelay! Ahura nosotros hemoste tener la culpa./ELISA.iY todavía habla esta chola! (69). 
En las palabras: “todavía habla”, está presente la falta de respeto al otro, lo que se pronuncia en el elegante living. De esta forma podemos ver que el dramaturgo hace uso de un espacio criollo para dar cuenta nuevamente de un conflicto, ahora presente entre la madre criolla y la madre chola. Según Balme (2013), el living es utilizado por "la dramaturgia realista occidental por excelencia y, como tal, fue adoptado al momento de escoger el escenario de sus obras, por dramaturgos indios que trabajaban de modo realista" (10). Ahora bien, el dramaturgo utiliza el living room como el espacio donde la madre chola embiste las descalificaciones de la criolla: "FAUSTINA: Ya, ya. Chola, dice. iChola, dice y de la chola están queriendo quitarle su hija! iNo se han de salir con su gusto! iPa algo' ps una tiene plata, pa algo' ps una pasado su vida comida o sin comer! iNo se han de estar haciendo la pava de mí! iHey de preferir quedarme en la calle pero no se han de salir con su gusto!" (69-70). En este espacio Faustina, la madre chola no se deja acallar y resiste.

Aquí, además es donde el hijo de la criolla, en tensión con lo cholo, reconoce su error:

Willy.- Si a Mary puede acusársele de mentir para aparentar otra cuna, a nosotros se nos debe reprochar de existir un mundo que no nos pertenece...Creo que mi reflexión no puede ser más sensata: deseo trabajar. No importa cómo ni de qué, pero será imposible seguir merced a la limosna de nuestras relaciones. Ahí está mi padre: amargado; con una vejez prematura como avergonzado de sí mismo” (73).

El espacio el living room revela una realidad. Esto es, el deseo de ascender socialmente presente en la hija chola y el deseo de ascender económicamente presente también en el criollo. Luego, la declaración de Willy es disidente de lo señalado por Alcides Arguedas, vocero de un discurso anticholo, ya que en este espacio homogeneizado, el criollo propone una alianza: “iWILLY.-Quiero a Mary y será mi esposa!” (72).

Soruco Sologuren (2011) señala:

Alcides Arguedas condena la mezcla de sangres como una enfermedad que imposibilita el progreso nacional. Esta literatura identifica el "problema de los cholos", su acumulación económica, ascenso social y alianzas familiares (matrimonios exogámicos) como amenazas para la sobrevivencia de los criollos como casta "no contaminada" (130). 
En el elegante living room se cumple lo que el historiador boliviano repudia. En este lugar además, la hija de chola pide perdón a la madre y retorna a su hogar: "MARY.- Cállate mamita y perdóname ċquieres? iSoy una mala hija! ¿Me perdonas, mamacita, me perdonas?” (71). Así, el living es el lugar donde la hija de la chola y el criollo valoran el origen cholo; reconocimiento que da cuenta de la coexistencia y resistencia de la alteridad latinoamericana.

\section{Conclusión}

La obra en estudio de Salmón pone en escena a personajes cholos que habitan y transitan en espacios híbridos, algunos de ellos son negados sobre todo por la hija de chola, la cual en el inicio y desarrollo de la obra niega su origen y huye con aquel que aborrece lo cholo. Por ello, la madre chola va en busca de ella y no se deja acallar ante aquellos que desean silenciarla, lo que da cuenta de su firmeza. Una identidad chola que subsiste en espacios urbanos, negociando sus saberes (García Canclini, 2010) y en "este cabalgar entre dos mundos" (Javier Albó et al., 1983: 12), transporta sus costumbres campesinas a la ciudad. De ahí que un ejemplo de hibridación sería la mixtura de aguayos indígenas con alfombras que combinan con el tapiz de las sillas. Esta combinación de prácticas de parte de la madre chola genera incomodidad en la aristocracia criolla; de este modo tratarán de excluirla o influenciar a la hija para que la niegue. Podemos ver entonces, que estos espacios teatrales no solo dan cuenta de una mixtura sino además dan a conocer la diferencia entre una familia criolla: "ambiente de elegancia y refinamiento y buen gusto" (57); y una familia chola: "salita criolla que posee alfombras que guardan relación con el tapizado de los muebles, y las paredes adornadas con pequeños aguayos indígenas colocados en sentido romboidal" (35). Así, la escenografía de la obra refiere a la diferencia social entre las sociedades de castas figuradas en el criollo y, los cholos, los cuales se caracterizan por su hibridez. Esto no está dicho en los diálogos de los personajes, sino que se desprende de la voz del acotador. De ahí que su voz es tan interdependiente del espacio como lo es la voz de los personajes.

En síntesis, en cada uno de estos espacios de la obra Joven, rica y plebeya hemos visto de qué forma transita el cholo, en algunos, su represión 
es severa, en otros, existe un despliegue de su identidad, la cual va acompañada de ambigüedades y contradicciones, lo que es propio de su identidad. Finalmente, el reconocimiento del origen (indígena y español) ocurre en el living room, donde la hija se arrepiente y pide perdón; y donde además se explicita el deseo del criollo de casarse con la chola. Esta alianza permite que estos espacios homogeneizados se conviertan en espacios heterogéneos, lo que resulta transgresor para la elite letrada de mediados del siglo XX. La obra Joven rica y plebeya, Hijo de chola permite discutir sobre conflictos sociales presentes en aquella época: la exclusión, la falta de respeto al otro, la falta de valoración a la alteridad latinoamericana. Los espacios cholos son el puente que posibilita una transformación en los personajes que niegan su identidad, y a la vez una interpelación al lector y espectador que se traduce en reconocer el utilitarismo de parte del proyecto político hegemónico de mediados del siglo XX, el que como ya sabemos propone la exclusión del cholo de los espacios urbanos y un protagonismo del mestizo letrado. Salmón remite a una literatura ancilar que lucha por transformar una sociedad desigualitaria, discute además en su obra Joven, rica y plebeya el asunto de la identidad chola que recibe la descalificación del criollo en la ciudad. En este espacio, no puede tener voz, tampoco independencia, así lo ha ordenado la elite letrada. No obstante, los personajes cholos sobre todo la madre es autónoma y lucha para resistir los embates del criollo, dando testimonio de un contexto histórico boliviano (el cual como ya lo he señalado no acepta la diferencia).

\section{Referencias}

Albó, X., Greaves, T. y Sandoval, G. (1983). Chukiyawu. La cara aymara de La Paz: III. Cabalgando entre dos mundos. La Paz: Cipca.

Arguedas, Alcides. Pueblo enfermo. 1979[1909]. La Paz, Bolivia: Puerta del Sol.

Balme, Cristopher. (2013). Introducción a los estudios teatrales. Santiago de Chile: Frontera Sur.

Boal, Augusto. 2002. Teatro del oprimido I. Teoría y Práctica. Barcelona, España: Alba. 
Bueno, Raúl. (1991) Escribir en Hispanoamérica ensayos sobre teoría crítica literaria. Lima: Latinoamericana Editores.

Cornejo Polar, Antonio. (1994). Escribir en el aire. Ensayos sobre la heterogeneidad socio-cultural en las literaturas andinas. Lima: Paidós.

Fernández Retamar, Roberto. (1976). Para una teoría de la literatura hispanoamericana. México: Nuestro Tiempo.

García Barrientos, José Luis. (2012). Cómo se comenta una obra de teatro: ensayo de método. México: tomo Editores y Producciones Escénicos y Cinematográficos: Paso de Gato.

García Canclini, Néstor. (2010). Culturas híbridas. Estrategias para entrar y salir de la modernidad. Argentina, Buenos Aires: Paidós.

Montecino, Sonia. (2010). Madres y huachos. Alegorías del mestizaje chileno. Santiago de Chile: Catalonia.

Moraña. Mabel. (2003). Prólogo en Escribir en el aire. Ensayos sobre la heterogeneidad socio-cultural en las literaturas andinas. Lima: Latinoamericana Editores. Recuperado de https://span590.files.wordpress.com/2011/o2/cornejo_escribir1.pdf

Rincón, Carlos. (1978). El cambio actual de la noción de literatura y otros estudios de teoría y crítica latinoamericana. Biblioteca colombiana de cultura colección autores nacionales.

Ruiz, Raúl. (1998). El Prometeo de los Andes. Buenos Aires: Platina.

Salmón, Raúl. (1989[1949]). Joven, rica y plebeya. La Paz: Juventud.

Stéphan, Jérôme. 2011. Tres teatros de vanguardias Meyerhold- Fassbinder-Griffero. Santiago de Chile: ARCIS.

Soruco Sologuren, Ximena. (2011). La ciudad de los cholos. Mestizaje y colonialidad en Bolivia siglos XIX y XX. Lima: PIEB.

Tamayo, Franz. (1975[1910]). Creación de la pedagogía nacional. La Paz: Biblioteca del Sesquicentenario de la República.

Todorov, Tzvetan. (2003). La conquista de América. El problema del Otro. Buenos Aires: Siglo XXI.

Valdés, Adriana. (1989). "En torno a la cultura”, ponencia presentada en la reunión de expertos sobre la mujer y la cultura, CEPAL, Santiago de Chile, noviembre, 1989 en Madre y huachos. Alegorías del mestizaje chileno (2010) de Sonia Montecino. 


\section{Referencias online}

Ainsa, Fernando. (2007). Propuesta para una geopoética latinoamericana. Recuperado de file://C:/Users/HP/Downloads/20313-32438-1PB\%2O(3).pdf

Griffero, Ramón. (2011). Respuestas de a un cuestionario de Rocío Fumey. Poética: la dramaturgia del espacio. Recuperado de http://www.memoriachilena.cl/archivos2/pdfs/MCo046715.pdf 